\title{
Employees' entrepreneurial work shaped by human capital and shaping entrepreneurial intention: Spain, Denmark, Middle East and North Africa
}

\section{Asmaa Dahalla*, Abderrahim Barakat and Sanaa Haouata}

\author{
Hassan II University, \\ Casablanca, Morocco \\ Email: asmaadahalla@gmail.com \\ Email: abderrahim.barakat@gmail.com \\ Email: haouatasanaa@gmail.com \\ *Corresponding author
}

\section{Peter Theis Nordenbøge}

\author{
University of Southern Denmark, \\ Odense, Denmark \\ Email: nordenboege@gmail.com
}

\begin{abstract}
The interest of specialists in the entrepreneurial intent determinants study is that it has gradually emerged as a predictor of effective entrepreneurship. For this reason, this article seeks to understand the links between employees' human capital and their entrepreneurial intent through entrepreneurial work that would generate the desire to create a business in them. Our paper uses a linear hierarchical modelling based on a large sample of 58,664 employees aged 18 through 64 from 15 countries, made up of the GEM Adult Population Survey. Comparison between MENA region countries, Spain and Denmark highlights the overriding role of human capital in both entrepreneurial work and entrepreneurial intent. The major result of this analysis is the moderating effect of the context on the predictive variables in defining employees' entrepreneurial work and defining entrepreneurial intent.
\end{abstract}

Keywords: entrepreneurial work; entrepreneurial intention; MENA region; human capital; education; entrepreneurial competencies; comparative study; Spain; Denmark; North Africa.

Reference to this paper should be made as follows: Dahalla, A., Barakat, A., Haouata, S. and Nordenbøge, P.T. (2020) 'Employees' entrepreneurial work shaped by human capital and shaping entrepreneurial intention: Spain, Denmark, Middle East and North Africa', MENA J. Cross-Cultural Management, Vol. 1, No. 1, pp.42-62.

Biographical notes: Asmaa Dahalla is a $\mathrm{PhD}$ student, teacher attached to the Entrepreneurship and Organizational Management Laboratory, Hassan II University-Casablanca Morocco, and member of the Global Entrepreneurship Monitor-Morocco. Her five years of experience in research and teaching combined with her seven years of experience as a consultant and employee has given her a sufficient global vision to be able to engage in intrapreneurship research and employees' entrepreneurial intent combining the qualitative and 
quantitative approach, she is also Co-founder of the Social and Media Studies Institute 'SMSI' an institute that promotes scientific research and employability of young people through entrepreneurship.

Abderrahim Barakat is currently a $\mathrm{PhD}$ student in entrepreneurship affiliated to the Entrepreneurship and Organizational Management Laboratory, Hassan II University-Casablanca Morocco, and member of the Global Entrepreneurship Monitor-Morocco. In 2009, he obtained a Master's degree in Marketing and Organisational Communication at the National School of Business and Management. He is interested in quantitative studies of several issues such as business survival, growth expectations, entrepreneurial intention and motivation, and he is the author of a number of research papers. He has a long experience in higher education in economics and management in several institutions since 2012 .

Sanaa Haouata is a PhD student in Entrepreneurship field, teacher attached to the Research Laboratory in Entrepreneurship and Organizational Management at Hassan II University in Casablanca - Morocco, and member of the Global Entrepreneurship Monitor, Morocco. Her passion for scientific research and entrepreneurship was the basic factor to found the Social and Media Studies Institute (SMSI). This institution promotes scientific research in the fields of social sciences and media through which, a special attention is devoted to raising awareness and support for entrepreneurship, especially for start-up entrepreneurs.

Peter Theis Nordenbøge is an MSc in Economics and Business Administration Strategic Entrepreneurship from University of Southern Denmark. Graduated with his thesis; (2019) 'An empirical study of the effect of human and social capital on the entrepreneurial work and innate entrepreneurial intentions of employees', he continued this work by kind invitation to participate by both the guest editor and co-authors.

This paper is a revised and expanded version of a paper entitled 'Du capital humain à l'intention entrepreneuriale des employés, le rôle médiateur de l'intrapreneuriat : cas des employés du Moyen-Orient et Afrique du Nord, d'Espagne et du Danemark' presented at 2nd International Conference on Digital, Innovation \& Entrepreneurship \& Financing, Valencia, Spain, 2-3 December 2019.

\section{Introduction}

The term intrapreneur was created by Pinchot (1985) as a combination of the terms entrepreneur and intracorporate and describes employees working entrepreneurially within an existing organisation (Blanka, 2018). Hence intrapreneurship is characterised as entrepreneurship performed internally by employees within an existing organisation, also referred to as corporate venturing (Sharma and Chrisman, 1999), corporate entrepreneurship (Parker, 2011) or simply intrapreneurship (Bager et al., 2014; Blanka, 2018). The terms corporate entrepreneurship and intrapreneurship represent two different perspectives, or levels, within entrepreneurship research. Corporate entrepreneurship refers to management driven top-down innovative process with the stated goal of increasing organisational innovativeness through the creation of new product lines, 
departments or subsidiaries. Intrapreneurship, on the other hand, is characterised as individual employees entrepreneurial work to drive a bottom-up innovative development process, within the organisation (Bager et al., 2014; Blanka, 2018). Entrepreneurship is emphasised as a driver of innovation, growth and development both individual firm and societal levels. The intrapreneurs perform several of the same tasks that independent entrepreneurs also perform, but under different circumstances. The entrepreneurial employee works within a predefined organisational setup that through delivering knowledge and experience, supports the internal process of exploiting opportunities for the benefit of the focal organisation (Blanka, 2018; Parker, 2011; Schøtt, 2011). Hence entrepreneurial employees or intrapreneurs deliver value in terms of driving innovation within existing companies. Intrapreneurship is a new form of work that can be situated between routine work and entrepreneurship, in the sense that an intrapreneur differs from a routine employee by his entrepreneurial spirit, that allowing him to undertake within the firm where he works for the benefit of both parties, with less risk than the entrepreneur.

How do competencies affect employees' tendency to work entrepreneurially? Do employees' human capital increase the likelihood of working entrepreneurial as compared to employees working routinely? Does this same human capital influence their hold of an entrepreneurial intention and does employees' entrepreneurial work also affect their entrepreneurial intention? Through the lens of Global Entrepreneurship Monitor (GEM), this paper investigates empirically the effects of the employees' human capital on their entrepreneurial work and their entrepreneurial intent.

This article tries to enrich the scientific literature dealing with intrapreneurship, entrepreneurship and relations between the two, through the mobilisation of a set of theory and concepts leading to a validated conceptual framework later by a hierarchical modelling taking into account the peculiarities of the context.

\section{Theoretical background}

\subsection{Entrepreneurial work benefiting from education and competence}

Human capital theory is derived from the work of three economists from the 1960s namely, Theodore Schulz, Gary Becker and Jacob Mincer. Mincer introduced his model for calculating the internal rate of return for education in 1974. Mincer argued that an individual's acquisition of knowledge through each year of education would yield a return as increased yearly income and as such, an increase in the standards of living. The model states that at a discount rate of $5 \%$, each year of education increases a person's annual earnings by $5 \%$. Other studies have equally calculated the discount rates for education and found rates to vary between 5 and $15 \%$ per year of education (Hartog and Oosterbeek, 2007). A reason for the variation is that the rate of return for education differs between developed and developing countries, where the highest returns are found in developing countries, as the increase in knowledge per year of education is largest. The effects also vary with the educational level, where the largest returns are attributed to basic education (Psacharopoulos in Hartog and Oosterbeek, 2007). Psacharopoulos also shows that the effects of education differ between high school and university level, with the latter providing the largest rate of return. We know from previous studies that employees performing entrepreneurial work typically have a higher income than employees performing routine work (Schøtt, 2011). They are also typically better 
educated than employees performing routine work (Bager et al., 2010). As they are better educated and have a higher salary level it is expected that education will have a positive effect on the employee's entrepreneurial work. We will investigate this through the first hypothesis:

H1 Education affects entrepreneurial work positively.

The analysis of the literature review raised that much of the work that has focused on the intrapreneurship phenomenon has given much more focus to the analysis of organisational variables rather than the characteristics and skills of employees (Vargas-Halabí et al., 2017). However, this is a research track that is important for the analysis of variables likely to have a positive impact on the company's intrapreneurial environment. An employee who has entrepreneurial skills is expected to benefit the company in which he operates. In this perspective, Ma et al. (2016) consider that an intrapreneur is a person who has the ability to create, identify and exploit opportunities that can create value for the company, improve its competitive advantage and stimulate its growth. In another sense, intrapreneurship is the process through which an employee or group of employees identify and exploits opportunities for innovation, in order to create a new organisation (spin-off), renew an organisation or introduce a product innovation for an already existing organisation (Vargas-Halabí et al., 2017).

However, it should be noted that entrepreneurship education is involved in the development of entrepreneurial competencies, Lackéus (2014) distinguishes in this sense, between two categories of competencies: cognitive competencies and non-cognitive competencies. Cognitive competencies refer to knowledge (Kraiger et al., 1993) and all the intellectual competencies acquired through the education system (Fisher et al., 2008), while non-cognitive competencies refer to attitudes (Cotton, 1991; Fisher et al., 2008; Krueger, 2007; Murnieks, 2007) such as entrepreneurial identity, innovation, perseverance, self-efficacy and entrepreneurial passion.

In their turns, Vargas-Halabi et al. (2017) distinguish between cognitive, functional or behavioural competencies. Intrapreneurship competencies are considered, in other words, as essential quality standards for achieving productivity gains or work efficiency, which are considered from the employee's attributes such as knowledge, tools it mobilises for the realisation of a job, as well as its attitudes put at the service of the performance of the organisation (Hoffmann, 1999).

Ultimately, we point out that the managers of the organisations came to understand that, at present, the performance of an organisation is dependent on its ability to adapt to an increasingly moving and complex environment (Lizote et al., 2013), and requiring employees with entrepreneurial competencies that can help the company gain competitive advantage and therefore be more efficient. Hence the objective of our second hypothesis, which seeks to analyse the link between entrepreneurial competencies and the intrapreneurial spirit within organisations.

H2 Competence affects entrepreneurial work positively.

\subsection{Intention to benefit from education, competence, and entrepreneurial work}

An entrepreneurial act is a non-spontaneous behaviour (Kabir et al., 2017), which is why much research on the explanation of this phenomenon has been based on the theory of 
planned behaviour contributions (Kabir et al., 2017; Koe et al., 2012; Liñán and Fayolle, 2015; $\mathrm{Wu}$ and $\mathrm{Wu}, 2008)$.

Before analysing the variables that could have an impact on entrepreneurial intent, it seems important to us first to understand the meaning of this concept. In this sense, Thompson (2009) considers that entrepreneurial intent for an individual is situated between his entrepreneurial dispositions and his actions maintained to start his business. Similarly, $\mathrm{Wu}$ and $\mathrm{Wu}$ (2008) defined entrepreneurial intent as a necessary process before making a decision, they consider entrepreneurial intent to be 'the decision to initiate behaviour'.

Nevertheless, "the factors that determine the individual's decision to start a venture are still not completely clear" (Liñán et al., 2011). The literature review has progressed to the point where it is possible to distinguish the explanatory variables of entrepreneurial intent into categories. They include variables related to personality traits (McClelland, 1961), and so-called demographic variables (Robinson et al., 1991), which include factors such as age (Levesque and Minniti, 2006), sex (Minniti and Nardone, 2007), origin, religion, level of education, work experience (Cooper and Park, 2008). For this second category, we are interested in this paper, particularly in analysing the impact of education, competencies and work experience on the intention to become an entrepreneur.

In the case of education, our analysis of the literature review revealed that almost all of the research that attempted to study the impact of education on entrepreneurial intent focused on analysing the contribution of education to entrepreneurship. However, education in general seems to have a positive impact on entrepreneurial intent. According to West and Hore (1989), university education is likely to have an impact on three aspects: personal development and changes in attitudes and values, capacity building and ultimately strengthening social ties. Le (1999) confirms the existence of a link between education and the potential to become an entrepreneur. Similarly, Lucas (1978) explains that education builds management capacity in individuals and therefore influences the intention to become an entrepreneur. These are the qualities that will be beneficial for an entrepreneur. From this discussion, in what follows, we plan to test the following hypothesis:

H3 Education affects intention positively.

Competence is defined as an individual's ability to be effective or efficient in performing work or in relation to a given situation (Sandroto et al., 2018). However, according to Shermon (2004), two types of competencies can be distinguished: specific competencies that refer to knowledge and skills, and generic competencies, which are mainly related to personality traits and self-image. Let us transpose on entrepreneurial competencies, we find that they are also composed of specific and generic competencies (Spencer and Spencer, 2008). In this sense, Bird (2019) adopts the following definition: "Entrepreneurial competencies are defined as underling characteristics such as generic and specific knowledge, motives, traits, self-images, social roles, and skills which result in venture birth, survival, and/or growth."

Competencies play an important role in the success of entrepreneurship (Bird, 2019; Solesvik, 2018, 2017). While some entrepreneurial competencies are developed during the educational process, others refer to the individual's characteristics and are shaped through personal and professional experience (Brownell, 2006). 
At the individual level, intrapreneurs, due to their similarities with entrepreneurs (Parker, 2011), tend to have a higher entrepreneurial intention than routine employees (Bosma et al., 2011). However, some authors have focused on other human capital variables that may be related to entrepreneurial intent, such as risk tolerance, which is higher and more important for entrepreneurs than for intrapreneurs, as well as personality traits considered as predictors not only of entrepreneurial intent but also of intrapreneurship (Shaver and Scott, 1992), other authors have considered that risk-taking, which is not really a characteristic of the entrepreneurs (Low and MacMillan, 1988), may be perceived differently among individual entrepreneurs (Corman et al., 1988). In this sense, we are interested in studying the impact of competencies and entrepreneurial work with the intention to create a new venture, through the following hypothesis:

H4 Competence affects intention positively.

H5 Entrepreneurial work affects intention positively.

\subsection{Embeddedness in national context}

The literature refers to a set of interrelations between the national context and entrepreneurial intent, and a set of complex contextual influences must be taken into account, as they affect the way a person creates a new venture (Low and MacMillan, 1988). In this sense, according to Bird (1988), film's behaviour must be conceptualised in a reality that takes into consideration the overall entrepreneur's context by explaining that the social, political and economic context acts with the personal context on the entrepreneurial intention, through its influence on the rational and intuitive thinking that leads to an action. Some social, economic and political conditions contribute to a favourable context creation for entrepreneurship such as displacement (Shapero and Sokol, 1982). Entrepreneurship is the set's result of variables from the economic, social and cultural environment (Krueger, 1993). Doytch and Epperson (2012) argue that factors such as easy access to finance or favourable market dynamics create a desire to develop an idea while others hinder it. Audretsch et al. (2007) explain that entrepreneurship is a process led by policy makers responsible for designing and implementing regulations that provide a suitable environment to motivate entrepreneurs, they identify relevant government policies: taxation, social security systems and labour market legislation regarding hiring, "higher taxation reduces the level of profit opportunities (incentive effect), thus reducing entrepreneurship" (Audretsch et al., 2007).

Intent predicts behaviour, and attitudes towards behaviour will have an impact on intentions. Reasoned action theory suggests that there are two components to attitudes, one based on expectations and the other based on social norms (Ajzen and Fishbein, 1980), adding to this perceived behavioural control gives the Ajzen (1991) planned behaviour theory that explains human action. This individual's behaviour is linked to the environment in which he or she lives (Learned, 1992), an enabling environment would encourage entrepreneurship, and thus reinforce the entrepreneurial intention unlike an unfavourable environment.

Bosma et al. (2011) assert the existence of an indirect effect of the national context on intrapreneurship by transitivity, the national context has an indirect effect on intrapreneurship since it acts on education which in turn influences intrapreneurship. The higher the level of education, the higher the prevalence of intrapreneurship and the more 
likely it is that education is in the country: a high-income country has a higher proportion of well-educated people than a low-income country.

Entrepreneurial intent is influenced by the context in which the firm will operate, in the sense that a country's commercial and legal infrastructure can influence entrepreneurial intent (Moreno i Sánchez, 2018). The context therefore has an impact on entrepreneurial intent, but account must be taken of the different contexts that are not identical from one country to another, since programs to promote and support entrepreneurship differ from one country to another, which also applies to education systems. Which brings us to:

H6 The independent variables effects at the individual level differ from one country to another.

Figure 1 Conceptual framework

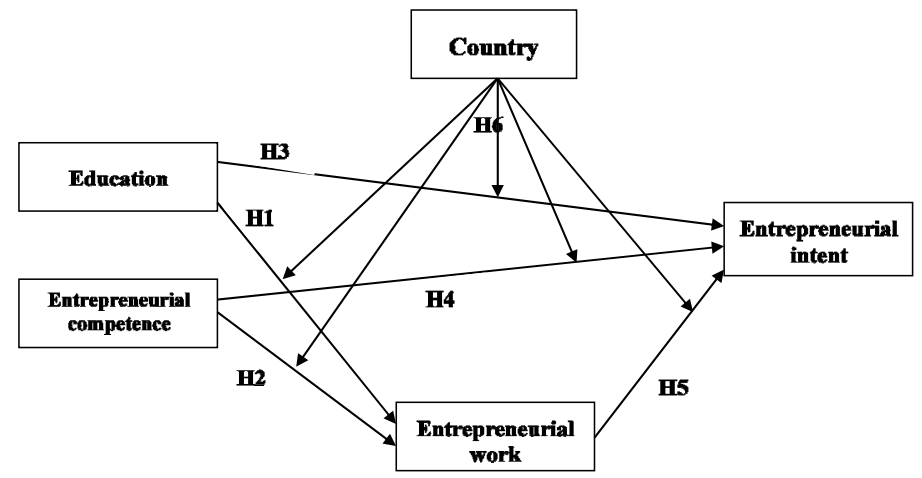

\section{Research design}

The population is a population of employees. To understand the relation between employees' human capital, their entrepreneurial work and the fact that engenders an entrepreneurial intention in them, we chose to sample employees from societies that differ. First of all, employees from Denmark where they are very likely to work entrepreneurially. Secondly, employees from societies in MENA region where employees are more likely to work routinely, and also from Spain where employees expectedly tend to be less entrepreneurial than those in Denmark and more entrepreneurial than those in MENA.

\subsection{Sampling}

Every year, researchers participating in the GEM program conduct a study among the adult population. The objective of the study is to understand the differences in motivation, intention and entrepreneurial activity in each country participating in the program. The relevance of the data from seems to be that it is possible to make comparisons between countries using a large sample. The observations came from about 15 countries, namely Spain, Denmark, Algeria, Egypt, Turkey, Iran, Morocco, Jordan, Kuwait, Lebanon, Tunisia, Saudi Arabia, Palestine, UAE and Qatar. The data is from the 
GEM Adult Population Questionnaire (APS) with the added special topic of entrepreneurial employee activity (EEA). The APS database gives us the possibility to isolate 58,664 employees aged 18 through 64, for which there is no lack of data on the variables used in the analysis.

Data are collected by telephone interviews in general and on face-to-face questionnaires in some countries. Respondents are selected by random probability sampling. Since probability random sampling is used and the sample size is large enough to allow us to affirm that the data are representative of the employee population in the countries studied.

\subsection{Measurements and variables description}

In order to correctly identify the predictive effect of the employee's human capital and his or her ability to perform entrepreneurial work on entrepreneurial intent, our model will take into account control variables such as the employee's gender and age. Gender takes the value 1 for a male employee and 0 for a female employee.

\subsubsection{Entrepreneurial intention}

Many entrepreneurship researchers consider entrepreneurial intent as an expression of personal will. It directs experience and action towards the objective of creating a firm. The entrepreneurial intent data used in our modelling are from the GEM database. The following question was addressed to adults, including the employees who make up the population of our research:

Are you, alone or with others, expecting to start a new business, including any type of self-employment, within the next three years?

There are differences in the level of entrepreneurial intent between countries. Employees living in MENA countries compared to Spain and Denmark. Employees in the MENA region have a greater entrepreneurial intention than employees living in the two western countries in our sample. $44.46 \%$ of employees in the MENA region expect to start a firm in a three-year period, compared to only $8.41 \%$ and $4.88 \%$ respectively in Denmark and Spain. Similarly, even within the MENA region, there are disparities in the entrepreneurial intent of employees. Jordan has the lowest entrepreneurial intention rate at $27.55 \%$ while Kuwait has the highest at $56.48 \%$ (Table 1 ).

\subsubsection{Entrepreneurial work}

Central for this paper is the identification of intrapreneurs and employees in possession of an entrepreneurial intention. The intrapreneurs are identified through the variable termed intrapreneurial work that identifies if the respondent: I'm working entrepreneurially through the question, "In the last three years, have you been involved in the development of new activities for your main employer, such as developing or launching new goods or services, or setting up a new business unit, a new establishment or subsidiary?"

In the MENA region, only $6.46 \%$ of employees report exercising entrepreneurial work in general, which is at a lower level than in Denmark (where $17.72 \%$ of employees are intrapreneurs). Kuwaiti employees are the most entrepreneurial and Tunisian employees are the ones who have less chance to undertake during their work activities (Table 1). 
Table 1 Variables description

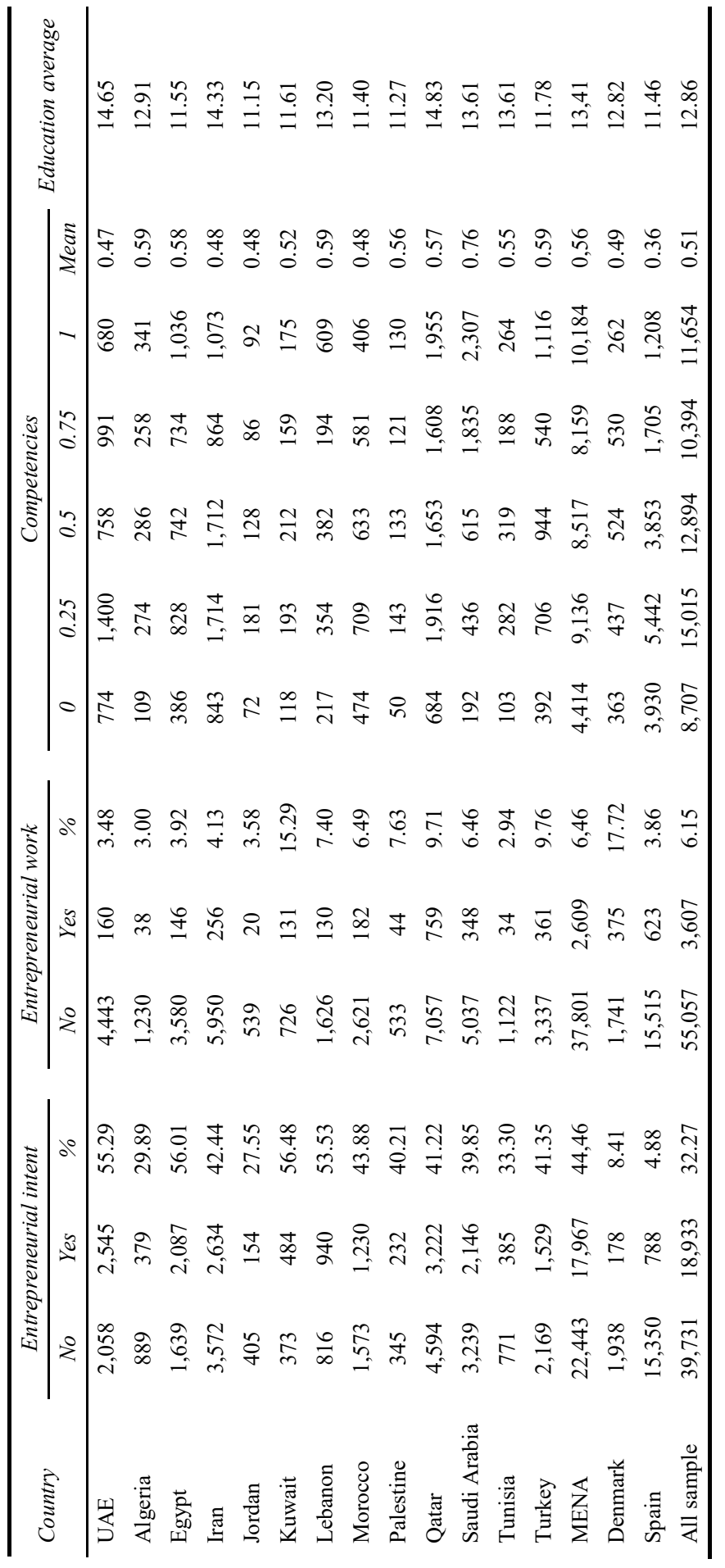




\subsubsection{Human capital: competencies and education}

Variable education is expressed in terms of the number of years the employee has spent in studies.

Among the countries covered by this research, Moroccan employees have the shortest duration of study, amounting to 11.40 years far behind Qatar, whose native employees have an average of 14.83 years.

Entrepreneurial competencies are measured as the average of four variables, namely self-efficacy, opportunity - alertness, risk willingness and role-modelling. In the GEM study, all four variables are binary variables, the relative ones are presented below.

- Role-modelling: Do you know someone personally who started a business in the past two years?

Coded 1 if the employee personally knows a contractor who can be an example to follow and 0 if not.

- Opportunity alertness: In the next six months, will there be good opportunities for starting a business in the area where you live?

It is a dichotomous variable coded 1 if recognising opportunity and 0 if not.

- Self-efficacy: Do you have the knowledge, skill and experience required to start a new business?

Dichotomous variable, 1 indicates the employee's confidence in his own ability to start and operate a business, 0 if he has a lack of confidence.

- $\quad$ Risk willingness: Would fear of failure prevent you from starting a business?

The dichotomous variable coded 1 if the employee does not fear failure and 0 if he does.

For our entire sample, the competencies average is 0.51 , which can be interpreted as follows: the employees in the sample have on average two out of the four competencies.

The MENA region as a whole has an average slightly higher: 0.56. Emirati employees report the lowest average entrepreneurial skills among the countries in the region, while in Saudi Arabia three quarters of the skills are reported as average. Spain is far downstream with only 0.36 as an average (Table 1 ).

\subsection{Technique for analysing the data}

Entrepreneurial intent is the result of a multidimensional and interactive set of factors, including the economic environment, social norms, opportunities and individual skills. The context of each country is different and the importance of each predictor variable varies from one country to another (Engle et al., 2010).

Our study attempts to clarify the effect of human capital on entrepreneurial intent by taking into account the mediating role of entrepreneurial work in a given context in order to make comparisons. We would like to highlight the specific characteristics of the employee and the national conditions that determine his or her entrepreneurial intent. Two levels of analysis were adopted to achieve the objective of our study, the first level of analysis is the country representing the particularity of the context in which an employee operates, and the second level focuses on employees, which has been 
approximated by all the other variables, namely entrepreneurial skills, duration of studies and entrepreneurial activity.

Multiple linear regression has many limitations and is not the best technique to address the issue of our model: first of all, it does not allow the effects of the context to be taken into account. Second, our sample is subdivided into as many subsamples as the number of countries covered by this research. In this case, a hierarchical linear model is more appropriate (Gelman and Hill, 2006). We will use hierarchical linear modelling in two steps. First, we will try to explain the activity and entrepreneurial work of an employee by his own human capital. The first phase of the model will also incorporate the country's moderating effect on human capital, which will allow us to highlight existing disparities between countries. Second, the model will attempt to clarify the role of human capital and entrepreneurial work in explaining entrepreneurial intent. The second part of the model also takes into account the country's moderating effect. The aim is to verify the assumptions schematised in Figure 1. In both stages of the model, the role of context is examined through comparisons whose reference country is Spain.

\section{Results}

\subsection{Description of the sample}

The correlation between the variables is presented in Table 2. First, all variables are significantly correlated to each other's. Secondly, all variables are independent and no correlation is as high as this to cause dependency between variables. The strongest correlation is observed between entrepreneurial intention and competencies (0.283). Since there is some correlation between the explanatory variables, a multicollinearity test was performed. Therefore, we used the variance inflation factor (VIF) test. The VIF shows us the extent to which the variance of the coefficient estimate is inflated by multicollinearity, as shown in Table 2, maximum VIF $=1,036$, so we conclude therefore, that no relevant multicollinearity is found between the variables.

Table 2 Means, standard deviations and correlations

\begin{tabular}{llcccccc}
\hline & 1 & 2 & 3 & 4 & 5 & 6 & VIF \\
\hline 1 Entrepreneurial intention & 1 & & & & & & \\
2 Intrapreneurial work & $0.091^{* *}$ & 1 & & & & & 1,023 \\
3 Education & $0.094^{* *}$ & $0.090^{* *}$ & 1 & & & & 1,030 \\
4 Competencies & $0.283^{* *}$ & $0.118^{* *}$ & $0.090^{* *}$ & 1 & & & 1,036 \\
5 Gender & $0.084^{* *}$ & $0.030^{* *}$ & $-0.036^{* *}$ & $0.104^{* *}$ & 1 & & 1,014 \\
6 Age & $-0.148^{* *}$ & $0.018^{* *}$ & $-0.117^{* *}$ & $-0.071^{* *}$ & $-0.009^{*}$ & 1 & 1,019 \\
Population & 58,664 & 58,664 & 58,664 & 58,664 & 58,664 & 58,664 & \\
Min & 0 & 0 & 1 & 0.00 & 0 & 18 & \\
Max & 1 & 1 & 25 & 1.00 & 1 & 79 & \\
Mean & 0.32 & 0.06 & 12.86 & 0.5054 & 0.66 & 37.21 & \\
SD & 0.468 & 0.240 & 4,241 & 0.33736 & 0.475 & 10,765 & \\
\hline
\end{tabular}

Notes: *P-value $<0.05 ; * *$ P-value $<0.01$. 


\subsection{Entrepreneurial work}

\subsubsection{The human capital general effects on employee entrepreneurial work}

Education affects employees' entrepreneurial work in a significant and positive way across the firms analysed in the 15 countries in general (Table 3). One additional year of training increases the probability that an employee will work as an entrepreneur by $0.51 \%$. Therefore, the effects of education are both positive and cumulative as a function of the duration of education. It should be noted that the values of education in our sample are from one to 25 years (Table 2). In other words, the effect of education is positive and increases the chances of employees to do entrepreneurial work.

Table 3 Entrepreneurial work predictors

\begin{tabular}{|c|c|c|}
\hline Dependent: intrapreneurial work & Main effects & Interactions \\
\hline Education & $0.0051^{*}$ & $0.0066^{*}$ \\
\hline Competence & $0.0775^{*}$ & $0.0466^{*}$ \\
\hline Gender & $0.0131 *$ & $0.0140^{*}$ \\
\hline Age & $0.0007 *$ & $0.0007 *$ \\
\hline Education * UAE & - & $-0.0044^{*}$ \\
\hline Education * Denmark & - & $0.0055^{*}$ \\
\hline Education * Algeria & - & $-0.0038^{*}$ \\
\hline Education $*$ Egypt & - & $-0.0020^{*}$ \\
\hline Education * Iran & - & $-0.0030^{*}$ \\
\hline Education $*$ Jordan & - & -0.0030 \\
\hline Education * Kuwait & - & $0.0075^{*}$ \\
\hline Education * Lebanon & - & -0.0026 \\
\hline Education * Morocco & - & 0.0001 \\
\hline Education * Palestine & - & 0.0026 \\
\hline Education * Qatar & - & -0.0004 \\
\hline Education * Saudi Arabia & - & $-0.0049 *$ \\
\hline Education $*$ Tunisia & - & $-0.0033^{*}$ \\
\hline Education $*$ Turkey & - & -0.0002 \\
\hline Education $*$ Spain & - & Ref. \\
\hline Competence * UAE & - & $0.0671 *$ \\
\hline Competence * Denmark & - & -0.0096 \\
\hline Competence * Algeria & - & $0.0221 *$ \\
\hline Competence * Egypt & - & 0.0064 \\
\hline Competence * Iran & - & $0.0535^{*}$ \\
\hline Competence $*$ Jordan & - & -0.0187 \\
\hline Competence * Kuwait & - & -0.0216 \\
\hline Competence $*$ Lebanon & - & 0.0176 \\
\hline
\end{tabular}

Notes: *P-value $<0.05$. Linear hierarchical modelling based on 15 countries with 58,664 employees. Spain is the reference country for comparisons. 
Table 3 Entrepreneurial work predictors (continued)

\begin{tabular}{lcc}
\hline Dependent: intrapreneurial work & Main effects & Interactions \\
\hline Competence * Morocco & - & 0.0219 \\
Competence * Palastine & - & $0.0636^{*}$ \\
Competence * Qatar & - & $0.0262^{*}$ \\
Competence * Saudi Arabia & - & 0.0173 \\
Competence * Tunisia & - & 0.0144 \\
Competence * Turkey & - & $0.1127^{*}$ \\
Competence * Spain & - & Ref. \\
Intercept & -0.0706 & -0.075 \\
\hline
\end{tabular}

Notes: *P-value $<0.05$. Linear hierarchical modelling based on 15 countries with 58,664 employees. Spain is the reference country for comparisons.

Competencies affect employees' entrepreneurial work in a significant and positive way in 15 countries analysed, in general. Each of the four skills used to calculate our variable gives the employee a $1.94 \%$ doing entrepreneurial work chance. An employee with competencies, as opposed to an employee who does not, has a $7.75 \%$ higher probability of working in an entrepreneurial manner than a routine job. Hence the competence of the employees and has a positive effect on their propensity to work in the firm in general.

\subsubsection{The national effects of human capital on employees' entrepreneurial work}

At the national level, however, the effects vary depending on the country in which a person is employed. The country's effects generally reduce the positive effect of education on employees' entrepreneurial work. On the one hand, compared to Spain, all MENA's country effect reduce the positive effect of education on entrepreneurial work except for Kuwait. On the other hand, for all countries with a significant effect on the role of skills in employees' chances of doing entrepreneurial work, Spanish employees for an equivalent level of skills have the lowest chances. Just as Turkish employees see their chances increase the most (Table 3).

Kuwait is the country where education increases the most employees' chances of doing entrepreneurial work among the countries in our sample, with $1.41 \%$ for each year of study. Denmark comes second with 1.21\% far ahead of Spain. Saudi Arabia represents the country where education has the least effect on the entrepreneurial work of employees (Table 4). Similarly, the Turkish context is the one that best values skills in granting entrepreneurial work. For an employee in Turkey, each skill adds $2.82 \%$ chance of doing entrepreneurial work compared to the reference country Spain.

This is indicative of the society, in which the employee is embedded, has an effect on their entrepreneurial work. This partially corroborates our H6 hypothesis. The structural framework within each country plays a significant role in how the individual employee leverage their human capital, hence country-specific factors such as management style in individual companies and the labour market in general, access to healthcare and education affect employees' choice of employment (Schøtt, 2011). 
Table 4 Entrepreneurial work model in Turkey, Denmark, Kuwait and Saudi Arabia

\begin{tabular}{ll}
\hline Country & \multicolumn{1}{c}{ Entrepreneurial work model } \\
\hline Turkey & $=-0.075+0.0066 *$ education $+0.0466 *$ competencies $+0.1127 *$ competencies \\
& $+0.014 *$ gender $+0.0007 *$ age \\
& $=-0.075+0.0066 *$ education $+0.1593 *$ competencies $+0.014 *$ gender \\
& $+0.0007 *$ age \\
Denmark & $=-0.075+0.0066 *$ education +0.0466 competencies $+0.0055 *$ education \\
& $+0.014 *$ gender $+0.0007 *$ age \\
& $=-0.075+0.0121 *$ education $+0.0466 *$ competencies $+0.014 *$ gender \\
& $+0.0007 *$ age \\
& $=-0.075+0.0066 *$ education $+0.0466 *$ competencies $+0.0075 *$ education \\
Kuwait & $+0.014 *$ gender $+0.0007 *$ age \\
& $=-0.075+0.0141 *$ education $+0.0466 *$ competencies $+0.014 *$ gender \\
Saudi & $=-0.0007 *$ age \\
Arabia & $+0.014 *$ gender $+0.0007 *$ age \\
& $=-0.075+0.0017 *$ education $+0.0466 *$ competencies $+0.014 *$ gender \\
& $+0.0007 *$ age
\end{tabular}

Note: Based on the modelling Table 3.

\subsection{Entrepreneurial intention}

\subsubsection{The general effects human capital and entrepreneurial work on employees' entrepreneurial intention: main effects}

The first result of our second part of the model is that education is not significantly related to entrepreneurial intent. This result invalidates our third hypothesis. The second one is that employees' entrepreneurial work in contrast to routine work, increases the probability of an employee being in possession of an entrepreneurial intention by $12.59 \%$.

Table 5 Entrepreneurial intention predictors

\begin{tabular}{lcc}
\hline Dependent: entrepreneurial intention & Main effects & Interactions \\
\hline Entrepreneurial work & $0.1259^{*}$ & $0.0830^{*}$ \\
Education & 0.0007 & -0.0010 \\
Competence & $0.2856^{*}$ & $0.0799^{*}$ \\
Gender & $0.0138^{*}$ & $0.0158^{*}$ \\
Age & $-0.0021^{*}$ & $-0.0022^{*}$ \\
Ent.Work * UAE & - & $0.1096^{*}$ \\
Ent.Work * Denmark & - & -0.0199 \\
Ent.Work * Algeria & - & $0.2726^{*}$ \\
Ent.Work * Egypt & - & 0.0154 \\
Ent.Work * Iran & - & $00810^{*}$ \\
Ent.Work * Jordan & - & $0.2074^{*}$ \\
Ent.Work * Kuwait & - & 0.0687 \\
\hline
\end{tabular}

Notes: *P-value $<0.05$. Linear hierarchical modelling based on 15 countries with 58,664 employees. Spain is the reference country for comparisons. 
Table 5 Entrepreneurial intention predictors

\begin{tabular}{|c|c|c|}
\hline Dependent: entrepreneurial intention & Main effects & Interactions \\
\hline Ent.Work * Lebanon & - & $0.1007 *$ \\
\hline Ent.Work * Morocco & - & $0.1983 *$ \\
\hline Ent.Work * Palestine & - & $0.1417^{*}$ \\
\hline Ent.Work* Qatar & - & $0.1109 *$ \\
\hline Ent.Work * Saudi Arabia & - & $-0.2217^{*}$ \\
\hline Ent.Work * Tunisia & - & 0.1265 \\
\hline Ent.Work * Turkey & - & 0.0299 \\
\hline Ent.Work * Spain & & Ref. \\
\hline Education * UAE & - & $-0.0042 *$ \\
\hline Education * Denmark & - & -0.0020 \\
\hline Education * Algeria & - & -0.0046 \\
\hline Education * Egypt & - & $0.0031^{*}$ \\
\hline Education * Iran & - & $0.0110^{*}$ \\
\hline Education * Jordan & - & -0.0039 \\
\hline Education * Kuwait & - & $0.0115^{*}$ \\
\hline Education * Lebanon & - & -0.0007 \\
\hline Education * Morocco & - & $0.0049 *$ \\
\hline Education * Palestine & - & 0.0076 \\
\hline Education * Qatar & - & -0.0025 \\
\hline Education * Saudi Arabia & - & $0.0088^{*}$ \\
\hline Education * Tunisia & - & $-0.0071 *$ \\
\hline Education $*$ Turkey & - & $-0.0049 *$ \\
\hline Education $*$ Spain & - & Ref. \\
\hline Competence $*$ UAE & - & $0.2195^{*}$ \\
\hline Competence * Denmark & - & $0.0676^{*}$ \\
\hline Competence * Algeria & - & $0.1536^{*}$ \\
\hline Competence $*$ Egypt & - & $0.2490^{*}$ \\
\hline Competence * Iran & - & $0.1425^{*}$ \\
\hline Competence * Jordan & - & $0.1688^{*}$ \\
\hline Competence $*$ Kuwait & - & $0.3426^{*}$ \\
\hline Competence * Lebanon & - & $0.3778^{*}$ \\
\hline Competence * Morocco & - & $0.2643^{*}$ \\
\hline Competence * Palastine & - & 0.0677 \\
\hline Competence * Qatar & - & $0.3967^{*}$ \\
\hline Competence * Saudi Arabia & - & $0.2628^{*}$ \\
\hline Competence $*$ Tunisia & - & $0.3059^{*}$ \\
\hline Competence * Turkey & - & $0.3779 *$ \\
\hline Competence $*$ Spain & - & Ref. \\
\hline Intercept & 0.2798 & -0.075 \\
\hline
\end{tabular}

Notes: *P-value $<0.05$. Linear hierarchical modelling based on 15 countries with 58,664 employees. Spain is the reference country for comparisons. 
Hence entrepreneurial work affects employees' entrepreneurial intention positively, as a general effect. The tasks associated with the internal entrepreneurial process is somewhat similar to those in the external process. Hence the increase in entrepreneurial skills has a positive effect on the possession of an entrepreneurial intention, every competence increase employee's chances to have entrepreneurial intention by $7.14 \%$. A competent employee has $28.56 \%$ more chance to have intention to create a new venture in comparison with an employee with none competencies.

Also as part of the attempt to understand the role of human capital in entrepreneurial intent, we found that male employees compared to their female counterparts are more likely to be entrepreneurial and that intent decreases with age.

\subsubsection{The national effects of human capital and entrepreneurial work on entrepreneurial intent}

The results of our modelling show a significant effect of each country's structural framework. The context and environment in each country influence the entrepreneurial intent of the employees within it. Entrepreneurial intent varies depending on the country in which a person is employed. Working in one country instead of another can decide whether the number of years of education will increase or decrease the employee's entrepreneurial intent. Working in Tunisia, for example, contrasts employee education with the chance that they have an entrepreneurial intention (negative coefficient), while in Saudi Arabia the more education the employee has, the more likely he or she is to have an entrepreneurial intention (Table 6).

Table 6 Entrepreneurial intent model in Denmark, Algeria, Qatar, Tunisia and Saudi Arabia

\begin{tabular}{ll}
\hline Country & \multicolumn{1}{c}{ Entrepreneurial intent model } \\
\hline Denmark & $=-0.075+0.083 *$ Ent.Work $+0.0799 *$ competencies $+0.0676 *$ competencies \\
& $+0.0158 *$ gender $-0.0022 *$ age \\
& $=-0.075+0.083 *$ Ent.Work $+0.1475 *$ competencies $+0.0158 *$ gender \\
& $-0.0022 *$ age \\
Algeria & $=-0.075+0.083 *$ Ent.Work $+0.0799 *$ competencies $+0.2726 *$ Ent.Work \\
& $+0.1536 *$ competencies $+0.0158 *$ gender $-0.0022 *$ age \\
& $=-0.075+0.3556 *$ Ent.Work $+0.2335 *$ competencies $+0.0158 *$ gender \\
& $-0.0022 *$ age \\
& $=-0.075+0.083 *$ Ent.Work $+0.0799 *$ competencies $+0.1109 *$ Ent.Work \\
Qatar & $+0.3967 *$ competencies $+0.0158 *$ gender $-0.0022 *$ age \\
& $=-0.075+0.1939 *$ Ent.Work $+0.3967 *$ competencies $+0.0158 *$ gender \\
Tunisia & $=-0.0022 *$ age \\
& $+0.3059 *$ competencies $+0.0158 *$ gender $-0.0022 *$ age \\
& $=-0.075+0.083 *$ Ent.Work $+0.3858 *$ competencies $-0.0071 *$ education \\
& $+0.0158 *$ gender $-0.0022 *$ age \\
Saudi & $=-0.075+0.083 *$ Ent.Work $+0.0799 *$ competencies $-0.2217 *$ Ent. Work \\
Arabia & $+0.0088 *$ education $+0.2628 *$ competencies $+0.0158 *$ gender $-0.0022 *$ age \\
& $=-0.075-0.1387 *$ Ent.Work $+0.3427 *$ competencies $+0.0088 *$ education \\
& $+0.0158 *$ gender $-0.0022 *$ age
\end{tabular}

Note: Based on the modelling Table 5. 
The other predictors of entrepreneurial intent tested by our modelling, namely entrepreneurial work and employees' skills, are also subject to the country effect. For entrepreneurial work, as for education, the variable is either positively or negatively related to entrepreneurial intention, depending on the country. There is a large gap between Saudi Arabia and Algeria, 49.43\% difference. For Saudi employees, the opportunity to do entrepreneurial work reduces entrepreneurial intent by $13.87 \%$, while for Algerian employees entrepreneurial work increases it by $35.56 \%$.

The difference noted in terms of average entrepreneurial intention between Spain and Denmark respectively $4.88 \%$ and $8.41 \%$ (Table 1 ) can be explained by the role of the context. The role of entrepreneurial skills on entrepreneurial intention is more important in Denmark than in Spain: 84.6\% more important (Table 6). In addition, in Spain, employees report $36.1 \%$ less competence than Danish employees (Table 1). The H6 hypothesis is also confirmed in the second stage of our model.

\section{Conclusions}

\subsection{Human capital effects on employee entrepreneurial work}

Human capital in the sense of both education and competencies affects employees' entrepreneurial work in Denmark, Spain and MENA region positively, as a general effect. This supports Hypotheses H1: education affects entrepreneurial work positively and $\mathrm{H} 2$ : competencies affect entrepreneurial work positively. Employees who have high level of education and competence will more often than employees lower educated and with a lower level of competence engage in entrepreneurial work. They will contribute to innovation and the creation of competitive advantages for the firm. Employee's entrepreneurial work is positively affected by the level of human capital, but some effect is also attributed to the structural framework within the individual countries. This indicates that countries can boost intrapreneurship through structural changes such as reducing the costs of education or making partnerships with companies for the promotion of an entrepreneurial career, by supplying intrapreneurs with favourable salary, further education possibilities and innovation. Through greater autonomy, entrepreneurial employees can increase innovation and create competitive advantages, thereby increasing firms' survival and competitiveness. Based on this, we can open the debate on the structural determinants that improve intrapreneurship within a country.

\subsection{Human capital and employees entrepreneurial work on entrepreneurial intention}

Education has no significant effect on entrepreneurial intent. H3: education affects intention positively is rejected. Higher educational level does not affect employee's intention positively, but competence does. H4: competence affects intention positively. This indicates that the combination of resilient self-efficacy, risk-willingness, opportunity-alertness and role-modelling plays a positive and significant role in employee's raise entrepreneurial intention - as well as employee's entrepreneurial work. H5: entrepreneurial work affects intention positively is confirmed. Employees' belief in themselves, their tolerance for risk and uncertainty, attentiveness towards new combinations of existing resources and social capital is vital for the intention towards the 
creation of a new organisation or subsidiary. Hence employees in possession of these competences should be valued as they drive innovation within companies. An exploration of the structural, cultural and managerial elements that determine the choice of delegated management would make it possible to approach employers to study their perceptions of employees with entrepreneurial competencies. The study would be a fertile basis for appreciating the extent to which firms make positive use of these competencies in intrapreneurial work.

All individual level effects differ from country to country further supporting the structural and cultural differences impact on both employees' entrepreneurial work and entrepreneurial intention. Hence the last Hypothesis H6: every individual level effect differs among countries is confirmed.

\section{Acknowledgements}

The authors would like to thank all those who helped to achieve this research, whether through advice, review or guidance, and acknowledge the remarkable work of the GEM teams that allowed to constitute the sample for this study.

\section{References}

Ajzen, I. (1991) 'The theory of planned behavior', Organizational Behavior Human Decision Processes, Vol. 50, No. 2, pp.179-211.

Ajzen, I. and Fishbein, M. (1980) Understanding Attitudes and Predicting Social Behaviour, Prentice Hall, Englewoods Cliffs.

Audretsch, D.B., Grilo, I. and Thurik, A.R. (2007) 'Explaining entrepreneurship and the role of policy: a framework', in Audretsch, D.B., Grilo, I. and Thurik, A.R. (Eds.): The Handbook of Research on Entrepreneurship Policy, pp.1-17, Edward Elgar Publishing, Cheltenham, UK.

Bager, T., Evald, M.R., Klyver, K. and Nielsen, S.L. (2014) Entrepreneurship in Theory and Practice: Paradoxes in Play, 1st ed., 2nd Reprint ed., Edward Elgar, Cheltenham.

Bager, T., Ottosson, H. and Schott, T. (2010) 'Intrapreneurs, entrepreneurs and spin-off entrepreneurs: similarities and differences', International Journal of Entrepreneurship and Small Business, Vol. 10, No. 3, pp.339-358.

Bird, B. (1988) 'Implementing entrepreneurial ideas: the case for intention', Academy of Management Review, Vol. 13, No. 3, pp.442-453.

Bird, B. (2019) 'Toward a theory of entrepreneurial competency', in Seminal Ideas for the Next Twenty-Five Years of Advances, pp.115-131, Emerald Publishing Limited.

Blanka, C. (2018). An individual-level perspective on intrapreneurship: A review and ways forward. Review of Managerial Science, 1-43.

Bosma, N., Stam, E. and Wennekers, S. (2011) Intrapreneurship versus Independent Entrepreneurship: A Cross-National Analysis of Individual Entrepreneurial Behavior, Vol. 11, No. 4, Discussion Paper Series/Tjalling C. Koopmans Research Institute.

Brownell, J. (2006) 'Meeting the competency needs of global leaders: a partnership approach', Human Resource Management Review, Vol. 45, No. 3, pp.309-336.

Cooper, S.Y. and Park, J.S. (2008) “The impact of incubator' organizations on opportunity recognition and technology innovation in new, entrepreneurial high-technology ventures', International Small Business Journal, Vol. 26, No. 1, pp.27-56. 
Corman, J., Perles, B. and Yancini, P. (1988) 'Motivational factors influencing high-technology entrepreneurship', Journal of Small Business Management, Vol. 26, No. 1, p.36.

Cotton, J. (1991) 'Enterprise education experience: a manual for school-based in-service training', Education + Training, Vol. 33, No. 4, pp.6-13.

Doytch, N. and Epperson, N. (2012) 'FDI and entrepreneurship in developing countries', Global Science and Technology Forum Business Review, Vol. 1, No. 3, pp.120-125.

Engle, R.L., Dimitriadi, N., Gavidia, J.V., Schlaegel, C., Delanoe, S., Alvarado, I., He, X., Buame, S. and Wolf, B. (2010) 'Entrepreneurial intent: a twelve-country evaluation of Ajzen's model of planned behavior', International Journal of Entrepreneurial Behavior \& Research, Vol. 16, No. 1, pp.33-57.

Fisher, B., Turner, K., Zylstra, M., Brouwer, R., De Groot, R., Farber, S. and Harlow, J. (2008) 'Ecosystem services and economic theory: integration for policy-relevant research', Ecological Applications, Vol. 18, No. 8, pp.2050-2067.

Gelman, A. and Hill, J. (2006) Data Analysis using Regression and Multilevel/Hierarchical Models, Cambridge University Press, Cambridge, doi: 10.1017/CBO9780511790942.

Hartog, J. and Oosterbeek, H. (2007) 'What should you know about private returns to education', in Hartog, J. and Maassen van den Brink, H. (Eds.): Human Capital: Advances in Theory and Evidence, pp.7-20, Cambridge University Press, Cambridge, doi: 10.1017/ CBO9780511493416.002.

Hoffmann, T. (1999) 'The meanings of competency', Journal of European Industrial Training, Vol. 23, No. 6, pp.275-286.

Kabir, M., Ibrahim, H.I. and Shah, K.A.M. (2017) 'Entrepreneurial competency as determinant for success of female entrepreneurs in Nigeria', Indonesian Journal of Business Entrepreneurship, Vol. 3, No. 2, p.143.

Koe, W-L., Sa'ari, J.R., Majid, I.A. and Ismail, K. (2012) 'Determinants of entrepreneurial intention among millennial generation', Procedia-Social Behavioral Sciences, Vol. 40, pp.197-208.

Kraiger, K., Ford, J.K. and Salas, E. (1993) 'Application of cognitive, skill-based, and affective theories of learning outcomes to new methods of training evaluation', Journal of Applied Psychology, Vol. 78, No. 2, p.311.

Krueger, J.N.F. (2007) 'What lies beneath? The experiential essence of entrepreneurial thinking', Entrepreneurship Theory Practice, Vol. 31, No. 1, pp.123-138.

Krueger, N. (1993) 'The impact of prior entrepreneurial exposure on perceptions of new venture feasibility and desirability', Entrepreneurship Theory Practice, Vol. 18, No. 1, pp.5-21.

Lackéus, M. (2014) 'An emotion based approach to assessing entrepreneurial education', The International Journal of Management Education, Vol. 12, No. 3, pp.374-396.

Le, A.T. (1999) 'Empirical studies of self-employment', Journal of Economic Surveys, Vol. 13, No. 4, pp.381-416.

Learned, K. (1992) 'What happened before the organization? A model of organization formation', Entrepreneurship Theory Practice, Vol. 17, No. 1, pp.39-48.

Levesque, M. and Minniti, M. (2006) 'The effect of aging on entrepreneurial behavior', Journal of Business Venturing, Vol. 21, No. 2, pp.177-194.

Liñán, F. and Fayolle, A. (2015) 'A systematic literature review on entrepreneurial intentions: citation, thematic analyses, and research agenda', International Entrepreneurship Management Journal, Vol. 11, No. 4, pp.907-933.

Liñán, F., Rodríguez-Cohard, J.C. and Rueda-Cantuche, J.M. (2011) 'Factors affecting entrepreneurial intention levels: a role for education', International Entrepreneurship Management Journal, Vol. 7, No. 2, pp.195-218.

Lizote, S., Verdinelli, M. and Silveira, A. (2013) 'Organisationnel factors and intrapreneurial competences’, International Journal of Innovation, Vol. 1, No. 1, pp.1-12. 
Low, M.B. and MacMillan, I.C. (1988) 'Entrepreneurship: past research and future challenges', Journal of Management, Vol. 14, No. 2, pp.139-161.

Lucas Jr., R.E. (1978) 'On the size distribution of business firms', The Bell Journal of Economics, pp.508-523.

Ma, H., Liu, T.Q. and Karri, R. (2016) 'Internal corporate venturing', Organizational Dynamics, Vol. 2, No. 45, pp.114-123.

McClelland, D. (1961) The Achieving Society, Van Nostrand, Princeton.

Minniti, M. and Nardone, C. (2007) 'Being in someone else's shoes: the role of gender in nascent entrepreneurship', Small Business Economics, Vol. 28, Nos. 2-3, pp.223-238.

Moreno i Sánchez, A. (2018) 'Environmental factors that affect the entrepreneurial intention', 950 Grau en Administració i Direcció d'Empreses, 60pp [online] https://ddd.uab.cat/record/ 191947 (accessed 8 July 2020).

Murnieks, C.Y. (2007) Who Am I? The Quest for an Entrepreneurial Identity and an Investigation of its Relationship to Entrepreneurial Passion and Goal-Setting, University of Colorado, Boulder.

Parker, S.C. (2011) 'Intrapreneurship or entrepreneurship?', Journal of Business Venturing, Vol. 26, No. 1, pp.19-34.

Pinchot, G. (1985) Intrapreneuring: Why You Don't Have to Leave the Corporation to Become an Entrepreneur, University of Illinois, Urbana-Champaign's Academy for Entrepreneurial Leadership Historical Research Reference in Entrepreneurship.

Robinson, P.B., Stimpson, D.V., Huefner, J.C. and Hunt, H.K. (1991) 'An attitude approach to the prediction of entrepreneurship', Entrepreneurship Theory Practice, Vol. 15, No. 4, pp.13-32.

Sandroto, C.W., Ramawati, Y. and Darmoyo, S.D. (2018) 'The role of competencies and education in increasing entrepreneurial intention in creative economy', Research Journal of Business Studies, Vol. 11, No. 1, pp.31-44.

Schøtt, T. (2011) Entrepreneurial Work by Employees in Enterprises-Studied via Global Entrepreneurship Monitor in Denmark, Jørn Thomsen Elbo A/S, Kolding.

Shapero, A. and Sokol, L. (1982) 'The social dimensions of entrepreneurship', Encyclopedia of Entrepreneurship, pp.72-90, University of Illinois at Urbana-Champaig"'s Academy for Entrepreneurial Leadership Historical Research Reference in Entrepreneurship [online] https://ssrn.com/abstract=1497759.

Sharma, P. and Chrisman, J.J. (1999) 'Toward a reconciliation of the definitional issues in the field of corporate entrepreneurship', Entrepreneurship Theory and Practice, Vol. 23, No. 3, pp.11-27.

Shaver, K.G. and Scott, L.R. (1992) 'Person, process, choice: the psychology of new venture creation', Entrepreneurship Theory Practice, Vol. 16, No. 2, pp.23-46.

Shermon, G. (2004) Competency based HRM: A Strategic Resource for Competency Mapping, Assessment and Development Centres, Tata McGraw-Hill Education, New Delhi.

Solesvik, M. (2018) 'The rise and fall of the resource-based view: paradigm shift in strategic management', Известия Уральского государственного экономического университета, Vol. 19, No. 4, pp.5-18.

Solesvik, M.Z. (2017) 'Hybrid entrepreneurship: how and why entrepreneurs combine employment with self-employment', Technology Innovation Management Review, Vol. 7, No. 3, pp33-41.

Spencer, L.M. and Spencer, P.S.M. (2008) Competence at Work Models for Superior Performance, John Wiley \& Sons, New York.

Thompson, E.R. (2009) 'Individual entrepreneurial intent: construct clarification and development of an internationally reliable metric', Entrepreneurship Theory Practice, Vol. 33, No. 3, pp.669-694. 
Vargas-Halabí, T., Mora-Esquivel, R. and Siles, B. (2017) 'Intrapreneurial competencies: development and validation of a measurement scale', European Journal of Management Business Economics, Vol. 26, No. 1, pp.86-111.

West, L.H. and Hore, T. (1989) 'The impact of higher education on adult students in Australia', Higher Education, Vol. 18, No. 3, pp.341-352.

$\mathrm{Wu}, \mathrm{S}$. and $\mathrm{Wu}, \mathrm{L}$. (2008) 'The impact of higher education on entrepreneurial intentions of university students in China', Journal of Small Business Enterprise Development, Vol. 15, No. 4, pp.752-774. 